\title{
Critical period of weeds interference in pineapple (Ananas comosus [L.] Merr.) crops
}

\author{
Silvana Pimentel de Oliveira ${ }^{(1)}$, Jefferson Costa Santos ${ }^{(1)}$, Bruna Nogueira Leite ${ }^{(1)}$, \\ Géssica Aline Nogueira dos Santos ${ }^{(1)}$, José Ferreira da Silva ${ }^{(2)}$
}

\author{
(1) Federal University of Amazonas. Graduate Program in Tropical Agronomy. Laboratory of Weed Science. Av. General \\ Rodrigo Octavio Jordão Ramos, 6200. Manaus - AM (Brazil).E-mail: silvanapimentel.oli@gmail.com \\ (2) Federal University of Amazonas. Department of Plant and Animal Production. Graduate Program in Tropical Agronomy. \\ Laboratory of Weeds Science. Av. General Rodrigo Octavio Jordão Ramos, 6200. Manaus - AM (Brazil).
}

Received 17 August 2020, accepted 26 April 2021, available online 17 May 2021.

This article is distributed under the terms and conditions of the CC-BY License (http://creativecommons.org/licenses/by/4.0)

Description of the subject. In crop-weed competition, some periods are critical because they may interfere with the crop production capacity. Therefore, knowing these periods is crucial when deciding on the best time for control and preparation of the Integrated Management Program.

Objectives. To determine the Period Prior to Interference, Total Period for Interference Prevention, and the Critical Interference Period in pineapple cultivation.

Method. The experimental design consisted of randomized blocks in $2 \times 15$ factorial arrangement, four replications, and two management systems: weeds control and crop-weeds coexistence; 15 increasing periods of 30 days each after planting: 0 , $30,60,90,120,150,180,210,240,270,300,330,360,390,420$. In the control treatments, since planting, manual weeding (with hoe) and mechanical weeding (with brush cutter) were done during increasing periods of time, and in the coexistence treatments, the weeds lived together with pineapple plants and, at the end of each period, weeds control was made with mechanical and chemical weeding.

Results. The best yields were achieved in the periods of less coexistence with weeds. The critical periods for interference prevention with 5 and $10 \%$ of yield losses were 259 and 204 days, respectively.

Conclusions. The critical period for interference prevention lasted 14-259 days after planting of the pineapple offsets.

Keywords. Weed competition, production capacity, weeding, agroecosystem, environmental sustainability, Amazon.

Période critique d'interférence des mauvaises herbes dans les cultures d'ananas (Ananas comosus [L.] Merr.)

Description du sujet. Lors de la compétition entre la culture et les plantes adventices ou mauvaises herbes, certaines périodes sont critiques, car celles-ci peuvent compromettre la capacité productive de la culture. Il semble par conséquent essentiel de connaître ces périodes pour le choix du moment favorable au contrôle, ainsi que pour l'élaboration du Programme de Conduite Intégrée.

Objectifs. Déterminer les périodes précoces, totales et tardives de nuisibilité dans la culture de l'ananas.

Méthode. L'essai est disposé en blocs factoriels randomisés en $2 \times 15$ avec quatre répétitions et deux systèmes de gestion : contrôle des adventices versus cohabitation avec les adventices ; 15 périodes croissantes de 30 jours après la plantation : 0 , $30,60,90,120,150,180,210,240,270,300,330,360,390,420$. Pour les traitements de désherbage, à partir de la plantation, le désherbage manuel (avec une bêche) et mécanique (avec une débroussailleuse) ont été employés par période croissante et, dans les traitements de cohabitation, les mauvaises herbes se sont développées avec la culture par période croissante. À la fin de chaque période, le désherbage mécanique et chimique a été réalisé.

Résultats. La production de la culture a été meilleure pour les modalités avec une moindre cohabitation avec les mauvaises herbes. La période critique de nuisibilité en fonction de la production de $5 \%$ et $10 \%$ de pertes ont été de 259 et 204 jours, respectivement.

Conclusions. La période critique de prévention de l'interférence des mauvaises herbes a duré 14-259 jours, après la plantation. Mots-clés. Compétition des adventices, capacité de production, désherbage, agroécosystème, durabilité environnementale, Amazonie. 


\section{INTRODUCTION}

Brazil is the third largest global producer of pineapple, a species of the family Bromeliaceae grown worldwide in the tropics (FAO, 2018). Because it is a slowgrowing plant and has surface roots, pineapple plants suffer greatly from competition with weeds, which contributes to delay the crop development and reduce yields (Reinhardt \& Cunha, 1984).

Numerous factors determine the degree of interference of weeds with a crop and these are related to the environment (climate, soil, weed community) and cultural practices (cultivar, spacing, plant density, fertilizers, irrigation, soil management, and weed management) (Ramos \& Pitelli, 1994).

Some periods during competition between weeds and crops are critical because they may affect yields. These periods were identified by Pitelli et al. (2013) as Period Prior to Interference (PPI) - during which, after emergence, the crop can coexist with weeds without reductions in production; Total Period for Interference Prevention (TPIP), - during which, after emergence, the weeds must be controlled to allow crops to manifest their full productive potential; and the Critical Interference Period (CIP), which is the time interval between the previous periods of the crop growth cycle, during which the weeds must be controlled to avoid unacceptable yield losses.

To manage weeds effectively, it is crucial to identify the species present in the cropping areas and determine the periods of interference, which indicate the time when control is no longer needed due to inexistent negative interactions between weeds and crops and the appropriate time to carry out weeds control (Marques et al., 2017).

The CIP is commonly reported as days after sowing/ planting (DAS/DAP), but due to differences in planting dates and the environment, this may generate results with higher variability between the planting locations, year seasons and cultivars tested (Anwar et al., 2012). Knowing CIP is vital when one has to decide on the best time for application of post-emergence herbicides and manual weeding (Ghanizadeh et al., 2010) and prepare the Integrated Weeds Management Program (Knezevic \& Datta, 2015).

Theoretically, weeds control before and after the CIP has no influence on crops production (Knezevic et al., 2002; Knezevic \& Datta, 2015); thus, the beginning and completion of CIP will depend on the acceptable level of crop yield losses.

There are few studies on the interference of weeds with pineapple cultivation in Brazil. According to Reinhardt \& Cunha (1984), the occurrence of weeds was more harmful to the pineapple $c v$. Perola in the first five months of the growing cycle. Catunda et al. (2006), studying how weeds affect growth and nutrients uptake of pineapple plants, identified NPK reduction in the pineapple D leaf after 30 days, as a function of density. Model et al. (2010) assessed the effect of weeds control treatments on pineapple productivity, health and quality and found the need for weeding during 296 days to achieve higher crop yields.

Due to environmental differences and the most varied competitive strategies of weeds, it is necessary to study the interference of these plants in pineapple crops in the Amazonian conditions. Thus, this research aimed to determine the Period Prior Interference and the Total Period for Interference Prevention (TPIP) and, from these, the Critical Interference Period (CIP) in pineapple crops in the municipality of Itacoatiara/ AM.

\section{MATERIALS AND METHODS}

The research was carried out during the 2016-2018 cropping years in an area belonging to the Associação dos Produtores da Comunidade do Sagrado Coração de Jesus - ASCOPE $\left(03^{\circ} 09^{\prime} 41,77^{\prime}\right.$ 'S $/ 59^{\circ} 09^{\prime} 59$, 30'W), an association of producers in the Vila do Engenho community, Itacoatiara, AM (Figure 1).

The study was in an area with $840 \mathrm{~m}^{2}$ that was previously used as pasture. The area remained as fallow for a period of four years. This is a common practice in the Amazon region. After removal of secondary cover plants, soil samples were collected for chemical and physical analysis at the Soil Fertility Laboratory/ ESALQ. The soil is Ultisol with a very clayed texture

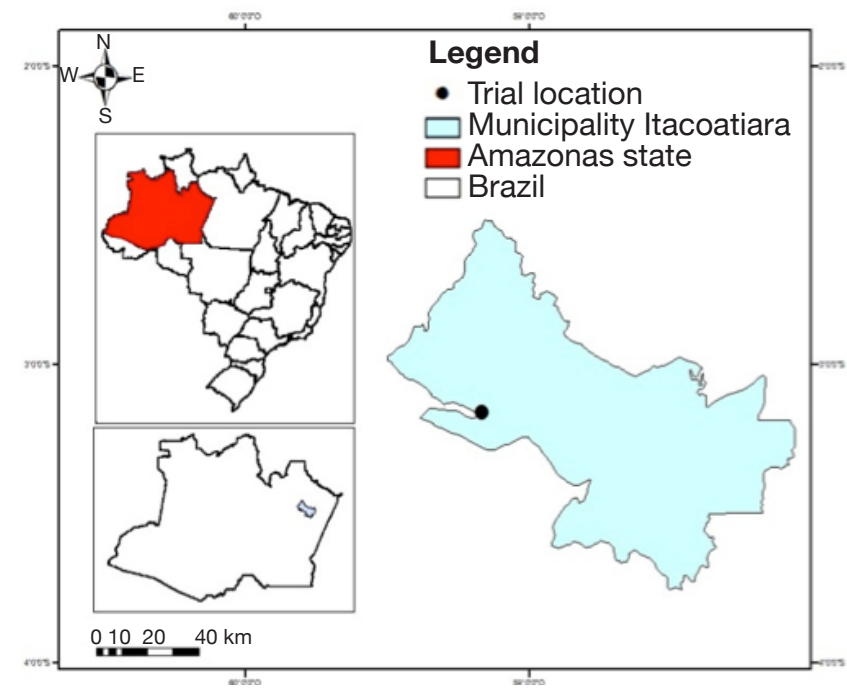

Figure 1. Map of location of the study area and the Sagrado Coração de Jesus/Vila do Engenho Community/Itacoatiara, $\mathrm{AM}$ - Carte de localisation de la zone d'étude et de la communauté Sagrado Coração de Jesus/Vila do Engenhol Itacoatiara, AM. 
$\mathrm{pH} 3.8 ; 33 \mathrm{dag} \cdot \mathrm{kg}^{-1}$ of organic matter $(\mathrm{OM})$ and $13 \%$ of base saturation (Table 1).

After weeding and grading, 2.5 tons of dolomite limes were applied to the area.

The pineapple cultivar used was BRS Turiaçu and the offsets were approximately $30 \mathrm{~cm}$ in length, coming from crops in the region. The propagation material underwent phytosanitary treatment, with immersion in a solution of thiamethoxam insecticide during $3 \mathrm{~min}$ and then placed in the shade for 15 days with the base facing upwards (Silva et al., 2004).

Planting was made 90 days after liming, in double rows, with spacing of $1.0 \times 0.40 \times 0.30 \mathrm{~m}$, totalizing 3,462 plants. The rows, $20 \mathrm{~m}$ in depth, were prepared the day before planting with a mixture of fertilizers and soil, at a rate of $175 \mathrm{~kg}$ of ammonium sulfate, $302 \mathrm{~kg}$ of potassium chloride, $473 \mathrm{~kg}$ of superphosphate and $31 \mathrm{~kg}$ of micronutrients (BR $12 \mathrm{R}$ ) per hectare.

Sixty days after planting, cover crop fertilization was conducted, and maintenance fertilization was made at the $5^{\text {th }}, 10^{\text {th }}$ and $12^{\text {th }}$ months with application of fertilizer into the soil to prevent the plants from burning and loss of nutrients (Silva et al., 2004). Floral induction occurred at the $10^{\text {th }}$ month with application of $100 \mathrm{~g} \cdot 15 \mathrm{l}^{-1}$ of calcium carbide (Melo, 2013).

The experimental design consisted of randomized blocks with $2 \times 15$ factorial arrangement and four replications. The factors consisted of two management systems: weeds control and crop-weeds coexistence, and 15 increasing periods of 30 days each after planting, namely, $0,30,60,90,120,150,180,210,240,270$, $300,330,360,390,420$. The plots comprised 16 plants with a line of pineapple plants as the border line at each end of the plot and $1 \mathrm{~m}$ apart from the side rows, and the four central plants of the central row of the plot were considered as the plants net area (Figure 2).
The experiment treatments comprised two groups, one of control and the other comprising pineapple and weeds coexistence.

In the control treatments, since planting, manual weeding (with hoe) and mechanical weeding (with brush cutter) were used for increasing periods of time and, at the end of each period, the weeds were left to grow freely in the experimental plots. In the crop-weed coexistence treatments, since planting, the weeds coexisted with the crop for increasing periods of time and, at the end of each period, weed control was made

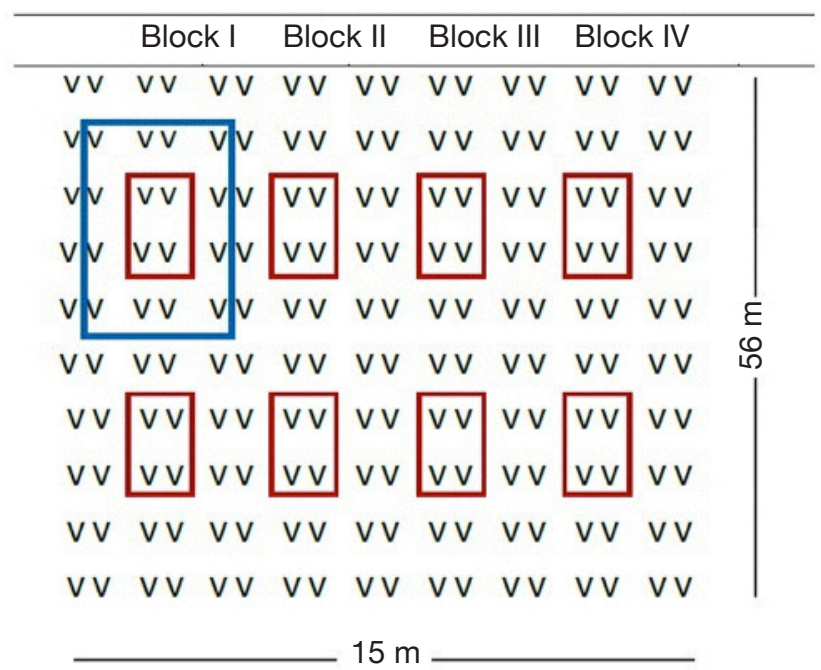

Figure 2. Design of part of the experiment for determination of the critical interference period (CIP) of weeds in pineapple crop - Conception d'une partie de l'expérience pour la détermination de la période critique d'interférence (CIP) des mauvaises herbes dans la culture de l'ananas.

Table 1. Chemical and physical characteristics of the soil in the experimental area - Caractéristiques chimiques et physiques du sol de la zone expérimentale (Itacoatiara, AM, 2016).

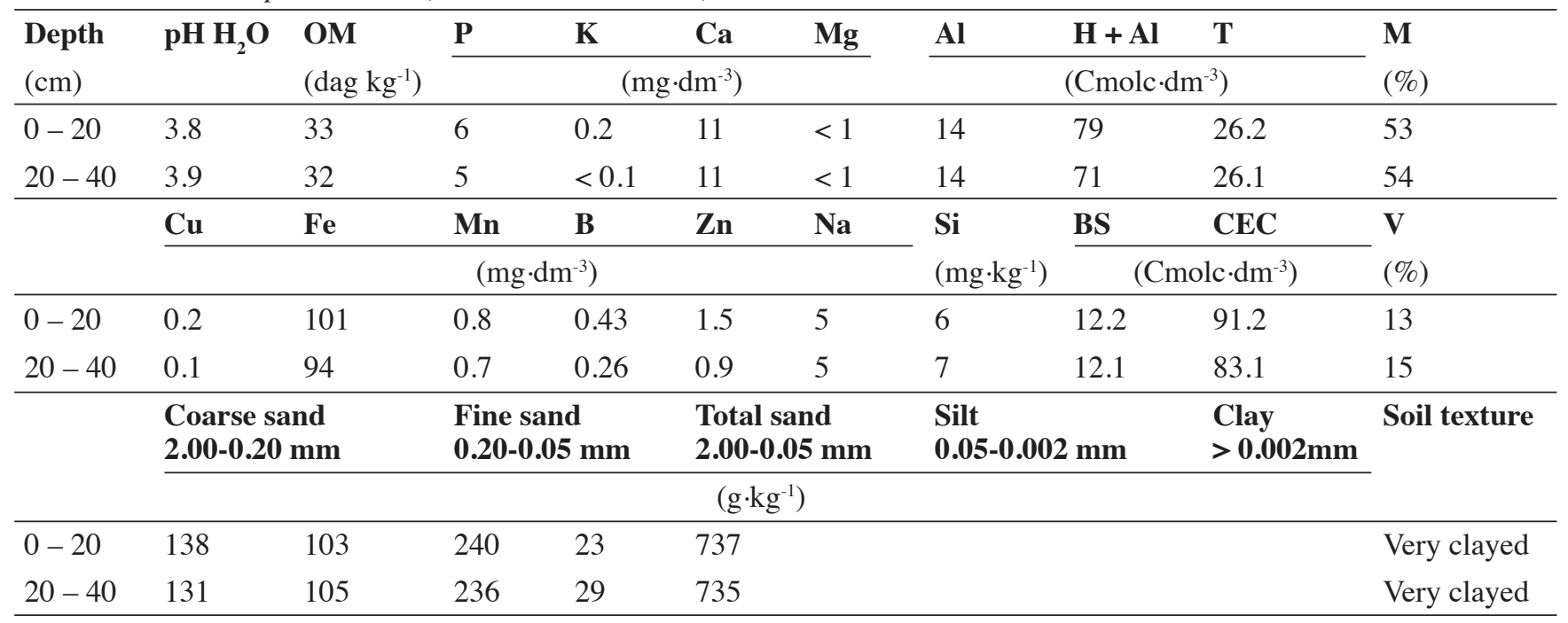


with mechanical and chemical weeding in the plots, which remained cleared until harvest (Table 2).

In chemical weeding, paraquat dichloride herbicide was used at a rate of $300 \mathrm{~g}$ of active ingredient (a.i.), which was sprayed onto the planting lines of the experimental units. The herbicide was applied with an electric backpack sprayer equipped with 110-02 fantype nozzles.

Five, 10 and 15 months after planting, samples of weeds present in the coexistence treatment were harvested, aiming to determine the floristic composition of the experimental area. A square wooden frame with an internal area of $0,25 \mathrm{~m}^{2}$ was used to collect the samples. The wooden frame was tossed twice into the row of plants.

The sampled plants in the square frame were cut near the root, separated, counted and were taken to the Laboratory of Weeds Science- LCPD of the Federal University of Amazonas - UFAM, to be identified. Identification of the species was carried out

Table 2. Months of control and pineapple-weeds coexistence in pineapple crop - Mois de contrôle et de coexistence ananas-mauvaises herbes dans la culture de l'ananas.

\begin{tabular}{|c|c|c|c|c|c|c|c|c|c|c|c|c|c|c|}
\hline \multicolumn{15}{|c|}{ Growth cycle (months) } \\
\hline 1st $^{\text {st }}$ & $2^{\text {nd }}$ & $3^{\text {rd }}$ & $4^{\text {th }}$ & $5^{\text {th }}$ & $6^{\text {th }}$ & $7^{\text {th }}$ & $8^{\text {th }}$ & $9^{\text {th }}$ & $10^{\text {th }}$ & $11^{\text {th }}$ & $12^{\text {th }}$ & $13^{\text {th }}$ & $14^{\text {th }}$ & $15^{\text {th }}$ \\
\hline $\mathrm{Ct}$ & $\mathrm{Ce}$ & $\mathrm{Ce}$ & $\mathrm{Ce}$ & $\mathrm{Ce}$ & $\mathrm{Ce}$ & $\mathrm{Ce}$ & $\mathrm{Ce}$ & $\mathrm{Ce}$ & $\mathrm{Ce}$ & $\mathrm{Ce}$ & $\mathrm{Ce}$ & $\mathrm{Ce}$ & $\mathrm{Ce}$ & $\mathrm{Ce}$ \\
\hline $\mathrm{Ct}$ & $\mathrm{Ct}$ & $\mathrm{Ce}$ & $\mathrm{Ce}$ & $\mathrm{Ce}$ & $\mathrm{Ce}$ & $\mathrm{Ce}$ & $\mathrm{Ce}$ & $\mathrm{Ce}$ & $\mathrm{Ce}$ & $\mathrm{Ce}$ & $\mathrm{Ce}$ & $\mathrm{Ce}$ & $\mathrm{Ce}$ & $\mathrm{Ce}$ \\
\hline $\mathrm{Ct}$ & $\mathrm{Ct}$ & $\mathrm{Ct}$ & $\mathrm{Ce}$ & $\mathrm{Ce}$ & $\mathrm{Ce}$ & $\mathrm{Ce}$ & $\mathrm{Ce}$ & $\mathrm{Ce}$ & $\mathrm{Ce}$ & $\mathrm{Ce}$ & $\mathrm{Ce}$ & $\mathrm{Ce}$ & $\mathrm{Ce}$ & $\mathrm{Ce}$ \\
\hline $\mathrm{Ct}$ & $\mathrm{Ct}$ & $\mathrm{Ct}$ & $\mathrm{Ct}$ & $\mathrm{Ce}$ & $\mathrm{Ce}$ & $\mathrm{Ce}$ & $\mathrm{Ce}$ & $\mathrm{Ce}$ & $\mathrm{Ce}$ & $\mathrm{Ce}$ & $\mathrm{Ce}$ & $\mathrm{Ce}$ & $\mathrm{Ce}$ & $\mathrm{Ce}$ \\
\hline $\mathrm{Ct}$ & $\mathrm{Ct}$ & $\mathrm{Ct}$ & $\mathrm{Ct}$ & $\mathrm{Ct}$ & $\mathrm{Ce}$ & $\mathrm{Ce}$ & $\mathrm{Ce}$ & $\mathrm{Ce}$ & $\mathrm{Ce}$ & $\mathrm{Ce}$ & $\mathrm{Ce}$ & $\mathrm{Ce}$ & $\mathrm{Ce}$ & $\mathrm{Ce}$ \\
\hline $\mathrm{Ct}$ & $\mathrm{Ct}$ & $\mathrm{Ct}$ & $\mathrm{Ct}$ & $\mathrm{Ct}$ & $\mathrm{Ct}$ & $\mathrm{Ce}$ & $\mathrm{Ce}$ & $\mathrm{Ce}$ & $\mathrm{Ce}$ & $\mathrm{Ce}$ & $\mathrm{Ce}$ & $\mathrm{Ce}$ & $\mathrm{Ce}$ & $\mathrm{Ce}$ \\
\hline $\mathrm{Ct}$ & $\mathrm{Ct}$ & $\mathrm{Ct}$ & $\mathrm{Ct}$ & $\mathrm{Ct}$ & $\mathrm{Ct}$ & $\mathrm{Ct}$ & $\mathrm{Ce}$ & $\mathrm{Ce}$ & $\mathrm{Ce}$ & $\mathrm{Ce}$ & $\mathrm{Ce}$ & $\mathrm{Ce}$ & $\mathrm{Ce}$ & $\mathrm{Ce}$ \\
\hline $\mathrm{Ct}$ & $\mathrm{Ct}$ & $\mathrm{Ct}$ & $\mathrm{Ct}$ & $\mathrm{Ct}$ & $\mathrm{Ct}$ & $\mathrm{Ct}$ & $\mathrm{Ct}$ & $\mathrm{Ce}$ & $\mathrm{Ce}$ & $\mathrm{Ce}$ & $\mathrm{Ce}$ & $\mathrm{Ce}$ & $\mathrm{Ce}$ & $\mathrm{Ce}$ \\
\hline $\mathrm{Ct}$ & $\mathrm{Ct}$ & $\mathrm{Ct}$ & $\mathrm{Ct}$ & $\mathrm{Ct}$ & $\mathrm{Ct}$ & $\mathrm{Ct}$ & $\mathrm{Ct}$ & $\mathrm{Ct}$ & $\mathrm{Ce}$ & $\mathrm{Ce}$ & $\mathrm{Ce}$ & $\mathrm{Ce}$ & $\mathrm{Ce}$ & $\mathrm{Ce}$ \\
\hline $\mathrm{Ct}$ & $\mathrm{Ct}$ & $\mathrm{Ct}$ & $\mathrm{Ct}$ & $\mathrm{Ct}$ & $\mathrm{Ct}$ & $\mathrm{Ct}$ & $\mathrm{Ct}$ & $\mathrm{Ct}$ & $\mathrm{Ct}$ & $\mathrm{Ce}$ & $\mathrm{Ce}$ & $\mathrm{Ce}$ & $\mathrm{Ce}$ & $\mathrm{Ce}$ \\
\hline $\mathrm{Ct}$ & $\mathrm{Ct}$ & $\mathrm{Ct}$ & $\mathrm{Ct}$ & $\mathrm{Ct}$ & $\mathrm{Ct}$ & $\mathrm{Ct}$ & $\mathrm{Ct}$ & $\mathrm{Ct}$ & $\mathrm{Ct}$ & $\mathrm{Ct}$ & $\mathrm{Ce}$ & $\mathrm{Ce}$ & $\mathrm{Ce}$ & $\mathrm{Ce}$ \\
\hline $\mathrm{Ct}$ & $\mathrm{Ct}$ & $\mathrm{Ct}$ & $\mathrm{Ct}$ & $\mathrm{Ct}$ & $\mathrm{Ct}$ & $\mathrm{Ct}$ & $\mathrm{Ct}$ & $\mathrm{Ct}$ & $\mathrm{Ct}$ & $\mathrm{Ct}$ & $\mathrm{Ct}$ & $\mathrm{Ce}$ & $\mathrm{Ce}$ & $\mathrm{Ce}$ \\
\hline $\mathrm{Ct}$ & $\mathrm{Ct}$ & $\mathrm{Ct}$ & $\mathrm{Ct}$ & $\mathrm{Ct}$ & $\mathrm{Ct}$ & $\mathrm{Ct}$ & $\mathrm{Ct}$ & $\mathrm{Ct}$ & $\mathrm{Ct}$ & $\mathrm{Ct}$ & $\mathrm{Ct}$ & $\mathrm{Ct}$ & $\mathrm{Ce}$ & $\mathrm{Ce}$ \\
\hline $\mathrm{Ct}$ & $\mathrm{Ct}$ & $\mathrm{Ct}$ & $\mathrm{Ct}$ & $\mathrm{Ct}$ & $\mathrm{Ct}$ & $\mathrm{Ct}$ & $\mathrm{Ct}$ & $\mathrm{Ct}$ & $\mathrm{Ct}$ & $\mathrm{Ct}$ & $\mathrm{Ct}$ & $\mathrm{Ct}$ & $\mathrm{Ct}$ & $\mathrm{Ce}$ \\
\hline $\mathrm{Ct}$ & $\mathrm{Ct}$ & $\mathrm{Ct}$ & $\mathrm{Ct}$ & $\mathrm{Ct}$ & $\mathrm{Ct}$ & $\mathrm{Ct}$ & $\mathrm{Ct}$ & $\mathrm{Ct}$ & $\mathrm{Ct}$ & $\mathrm{Ct}$ & $\mathrm{Ct}$ & $\mathrm{Ct}$ & $\mathrm{Ct}$ & $\mathrm{Ct}$ \\
\hline $\mathrm{Ce}$ & $\mathrm{Ct}$ & $\mathrm{Ct}$ & $\mathrm{Ct}$ & $\mathrm{Ct}$ & $\mathrm{Ct}$ & $\mathrm{Ct}$ & $\mathrm{Ct}$ & $\mathrm{Ct}$ & $\mathrm{Ct}$ & $\mathrm{Ct}$ & $\mathrm{Ct}$ & $\mathrm{Ct}$ & $\mathrm{Ct}$ & $\mathrm{Ct}$ \\
\hline $\mathrm{Ce}$ & $\mathrm{Ce}$ & $\mathrm{Ct}$ & $\mathrm{Ct}$ & $\mathrm{Ct}$ & $\mathrm{Ct}$ & $\mathrm{Ct}$ & $\mathrm{Ct}$ & $\mathrm{Ct}$ & $\mathrm{Ct}$ & $\mathrm{Ct}$ & $\mathrm{Ct}$ & $\mathrm{Ct}$ & $\mathrm{Ct}$ & $\mathrm{Ct}$ \\
\hline $\mathrm{Ce}$ & $\mathrm{Ce}$ & $\mathrm{Ce}$ & $\mathrm{Ct}$ & $\mathrm{Ct}$ & $\mathrm{Ct}$ & $\mathrm{Ct}$ & $\mathrm{Ct}$ & $\mathrm{Ct}$ & $\mathrm{Ct}$ & $\mathrm{Ct}$ & $\mathrm{Ct}$ & $\mathrm{Ct}$ & $\mathrm{Ct}$ & $\mathrm{Ct}$ \\
\hline $\mathrm{Ce}$ & $\mathrm{Ce}$ & $\mathrm{Ce}$ & $\mathrm{Ce}$ & $\mathrm{Ct}$ & $\mathrm{Ct}$ & $\mathrm{Ct}$ & $\mathrm{Ct}$ & $\mathrm{Ct}$ & $\mathrm{Ct}$ & $\mathrm{Ct}$ & $\mathrm{Ct}$ & $\mathrm{Ct}$ & $\mathrm{Ct}$ & $\mathrm{Ct}$ \\
\hline $\mathrm{Ce}$ & $\mathrm{Ce}$ & $\mathrm{Ce}$ & $\mathrm{Ce}$ & $\mathrm{Ce}$ & $\mathrm{Ct}$ & $\mathrm{Ct}$ & $\mathrm{Ct}$ & $\mathrm{Ct}$ & $\mathrm{Ct}$ & $\mathrm{Ct}$ & $\mathrm{Ct}$ & $\mathrm{Ct}$ & $\mathrm{Ct}$ & $\mathrm{Ct}$ \\
\hline $\mathrm{Ce}$ & $\mathrm{Ce}$ & $\mathrm{Ce}$ & $\mathrm{Ce}$ & $\mathrm{Ce}$ & $\mathrm{Ce}$ & $\mathrm{Ct}$ & $\mathrm{Ct}$ & $\mathrm{Ct}$ & $\mathrm{Ct}$ & $\mathrm{Ct}$ & $\mathrm{Ct}$ & $\mathrm{Ct}$ & $\mathrm{Ct}$ & $\mathrm{Ct}$ \\
\hline $\mathrm{Ce}$ & $\mathrm{Ce}$ & $\mathrm{Ce}$ & $\mathrm{Ce}$ & $\mathrm{Ce}$ & $\mathrm{Ce}$ & $\mathrm{Ce}$ & $\mathrm{Ct}$ & $\mathrm{Ct}$ & $\mathrm{Ct}$ & $\mathrm{Ct}$ & $\mathrm{Ct}$ & $\mathrm{Ct}$ & $\mathrm{Ct}$ & $\mathrm{Ct}$ \\
\hline $\mathrm{Ce}$ & $\mathrm{Ce}$ & $\mathrm{Ce}$ & $\mathrm{Ce}$ & $\mathrm{Ce}$ & $\mathrm{Ce}$ & $\mathrm{Ce}$ & $\mathrm{Ce}$ & $\mathrm{Ct}$ & $\mathrm{Ct}$ & $\mathrm{Ct}$ & $\mathrm{Ct}$ & $\mathrm{Ct}$ & $\mathrm{Ct}$ & $\mathrm{Ct}$ \\
\hline $\mathrm{Ce}$ & $\mathrm{Ce}$ & $\mathrm{Ce}$ & $\mathrm{Ce}$ & $\mathrm{Ce}$ & $\mathrm{Ce}$ & $\mathrm{Ce}$ & $\mathrm{Ce}$ & $\mathrm{Ce}$ & $\mathrm{Ct}$ & $\mathrm{Ct}$ & $\mathrm{Ct}$ & $\mathrm{Ct}$ & $\mathrm{Ct}$ & $\mathrm{Ct}$ \\
\hline $\mathrm{Ce}$ & $\mathrm{Ce}$ & $\mathrm{Ce}$ & $\mathrm{Ce}$ & $\mathrm{Ce}$ & $\mathrm{Ce}$ & $\mathrm{Ce}$ & $\mathrm{Ce}$ & $\mathrm{Ce}$ & $\mathrm{Ce}$ & $\mathrm{Ct}$ & $\mathrm{Ct}$ & $\mathrm{Ct}$ & $\mathrm{Ct}$ & $\mathrm{Ct}$ \\
\hline $\mathrm{Ce}$ & $\mathrm{Ce}$ & $\mathrm{Ce}$ & $\mathrm{Ce}$ & $\mathrm{Ce}$ & $\mathrm{Ce}$ & $\mathrm{Ce}$ & $\mathrm{Ce}$ & $\mathrm{Ce}$ & $\mathrm{Ce}$ & $\mathrm{Ce}$ & $\mathrm{Ct}$ & $\mathrm{Ct}$ & $\mathrm{Ct}$ & $\mathrm{Ct}$ \\
\hline $\mathrm{Ce}$ & $\mathrm{Ce}$ & $\mathrm{Ce}$ & $\mathrm{Ce}$ & $\mathrm{Ce}$ & $\mathrm{Ce}$ & $\mathrm{Ce}$ & $\mathrm{Ce}$ & $\mathrm{Ce}$ & $\mathrm{Ce}$ & $\mathrm{Ce}$ & $\mathrm{Ce}$ & $\mathrm{Ct}$ & $\mathrm{Ct}$ & $\mathrm{Ct}$ \\
\hline $\mathrm{Ce}$ & $\mathrm{Ce}$ & $\mathrm{Ce}$ & $\mathrm{Ce}$ & $\mathrm{Ce}$ & $\mathrm{Ce}$ & $\mathrm{Ce}$ & $\mathrm{Ce}$ & $\mathrm{Ce}$ & $\mathrm{Ce}$ & $\mathrm{Ce}$ & $\mathrm{Ce}$ & $\mathrm{Ce}$ & $\mathrm{Ct}$ & $\mathrm{Ct}$ \\
\hline $\mathrm{Ce}$ & $\mathrm{Ce}$ & $\mathrm{Ce}$ & $\mathrm{Ce}$ & $\mathrm{Ce}$ & $\mathrm{Ce}$ & $\mathrm{Ce}$ & $\mathrm{Ce}$ & $\mathrm{Ce}$ & $\mathrm{Ce}$ & $\mathrm{Ce}$ & $\mathrm{Ce}$ & $\mathrm{Ce}$ & $\mathrm{Ce}$ & $\mathrm{Ct}$ \\
\hline $\mathrm{Ce}$ & $\mathrm{Ce}$ & $\mathrm{Ce}$ & $\mathrm{Ce}$ & $\mathrm{Ce}$ & $\mathrm{Ce}$ & $\mathrm{Ce}$ & $\mathrm{Ce}$ & $\mathrm{Ce}$ & $\mathrm{Ce}$ & $\mathrm{Ce}$ & $\mathrm{Ce}$ & $\mathrm{Ce}$ & $\mathrm{Ce}$ & $\mathrm{Ce}$ \\
\hline
\end{tabular}

$\mathrm{Ct}$ : Control - témoin; Ce: Coexistence months - mois de coexistence. 
by comparison with specialized literature and with the specimens of the LCPD/UFAM collection. Class, family, scientific name and common name of the collected plants were identified.

At the end of the growing cycle, pineapples were harvested exhibiting 30 to $50 \%$ of yellow fruits, from the plant base to the apex.

Production was estimated considering the weight of the whole fruit with top crown of the plants, which were collected from the net area of each treatment, which was converted into productivity, or yield, expressed in $\mathrm{kg} \cdot \mathrm{ha}^{-1}$, by means of the following formula:

Productivity $=$ fruits weight $(\mathrm{kg}) \times$ number of plants $\cdot h \mathrm{~h}^{-1}$.

The data relating to productivity was subjected to analysis of variance (ANOVA) and the means were compared by the Scott-Knott test $(p \leq 0.05)$ using the ASSISTAT 7.0 software program.

The productivity means were subjected to regression analysis with curves fitting using the following models: Boltzmann's Sigmoid and Linear. To define the regression equation, the logic of the biological phenomena and the value of the coefficient of determination $\left(\mathrm{R}^{2}\right)$ were considered.

The PIP and TPIP were determined based on regression equations, considering the yields in the periods of $0,30,60,90,120,150,180,210,240$, $270,300,330,360,390$ and 420 days of control and coexistence with weeds, respectively. Based on the difference between the TPIP and PIP, we obtained the critical period for interference prevention (CPIP) for the assumed tolerance levels of 5\% and $10 \%$ in yield reduction in relation to the weeds control treatment for the entire crop cycle.

To carry out the regression analyses, the Origin 2019 software (OriginalLab Corporation, USA) was used.

\section{RESULTS}

\subsection{Floristic composition of the weeds found in the experimental area}

Table 3 shows the results of the floristic survey of weeds that interfere with the pineapple crop, comprising 30 species distributed into 11 botanic families.

\subsection{Productivity and periods of weeds interference}

The management and periods of weeds control and weed-crop coexistence affected the productivity of the pineapple crop. Data from the control treatments indicated better mathematical fit in Boltzmann' sigmoidal equation while data from the weed-crop coexistence treatment fitted properly in the Linear equation (Table 4).

Figure 3 illustrates the pineapple production as a function of increasing periods of control and weeds coexistence with pineapple crop.

The highest crop yields were found in the treatments where the weed control occurred during the whole growing cycle, and an opposite effect (lowest crop yields) was found in the treatments with weed crop coexistence throughout the growing cycle, with $69.5 \%$ of yield losses.

In the crop-weed coexistence treatment throughout the growing cycle, there was absence of fruiting in some plants in the net areas of the plots, fruits with no commercial value and delay in fruiting and fruits ripening, and these results are similar to the ones obtained by Reinhardt \& Cunha (1984) when they determined the critical period of competition of weeds with pineapple $c v$. Perola.

The periods of control and coexistence and the critical period of interference prevention (CPIP) of the weeds with the crop were determined based on the regression equations, assuming 5\% and $10 \%$ of yield losses as tolerance levels (Table 5), considering that minor losses caused by weed interference do not justify economically the application of control methods.

Considering acceptable maximum losses of $5 \%$, the pineapple productivity was adversely affected by the presence of weeds after 14 DAP (PPI), requiring control up to 273 DAP (TPIP). The 259 days within the period between 14 and 273 DAP correspond to the critical period for interference prevention (CPIP).

\section{DISCUSSION}

\subsection{Floristic composition of weeds grown in the experimental area}

Considering the 11 botanic weed families that were found during the experiment, the most representative weeds in number of species were Poaceae (seven) and Cyperaceae (six), followed by Asteraceae and Solanaceae (three), Amaranthaceae, Euphorbiaceae, Lamiaceae and Rubiaceae (two), and the other families had only one representative species. The largest number of species belongs to the Dicotyledon class, but the largest density of species per family was observed for the Monocotyledon class.

The high rainfall that occurred in the region from December 2016 to April 2017, the first months after planting and crop-weeds coexistence, certainly favored the establishment of weed populations.

Most of the weed species occurred along the pineapple growing cycle, except Cantinoa Americana (Aubl.) Harley \& J.F.B.Pastore, Urochloa 
Table 3. Floristic composition of weeds found in the experimental area according to class, family, scientific name, common name, and code - Composition floristique des mauvaises herbes trouvées dans la zone expérimentale selon la classe, la famille, le nom scientifique, le nom commun et le code.

\begin{tabular}{|c|c|c|c|c|}
\hline Class & Family & Species & Common name & Code \\
\hline \multirow[t]{14}{*}{ Monocotyledons } & Commelinaceae & Commelina benghalensis L. & $\begin{array}{l}\text { Benghal dayflower/tropical } \\
\text { spiderwort }\end{array}$ & COMBE \\
\hline & \multirow[t]{6}{*}{ Cyperaceae } & Cyperus articulatus L. & Jointed flatsedge & CYPAR \\
\hline & & Cyperus diffusus Vahl & Diffused flatsedge & CYPDF \\
\hline & & Cyperus esculentus L. & Yellow nutsedge & CYPES \\
\hline & & Cyperus rotundus $\mathrm{L}$. & Nutgrass & CYPRO \\
\hline & & Rhynchospora corymbosa (L.) Britton & Capim navalha & RHCAU \\
\hline & & Rhynchospora nervosa (Vahl) Boeckeler & Estrelinha & CYPKY \\
\hline & \multirow[t]{7}{*}{ Poaceae } & Digitaria bicornis (Lam.) Roem. \& Schult. & Asian crabgrass/finger grass & DIGBC \\
\hline & & Digitaria horizontalis Willd. & Jamaican crabgrass & DIGHO \\
\hline & & Digitaria insularis (L.) Mez ex Ekman & Sourgrass & TRCIN \\
\hline & & Eleusine indica (L.) Gaertn. & Goosegrass, yardgrass & ELEIN \\
\hline & & Panicum maximum Jacq. & Guinea grass & PANMA \\
\hline & & Urochloa brizantha (A.Rich.) R.D. Webster & Polisade grass & BRABR \\
\hline & & Urochloa eminii (Mez) Davidse & Signal grass/sheep grass & BRARU \\
\hline \multirow[t]{16}{*}{ Dicotyledons } & \multirow[t]{2}{*}{ Amaranthaceae } & Alternanthera ficoidea (L.) Sm. & Parrotleaf/calicoplant & ALRFI \\
\hline & & Amaranthus deflexus L. & Large-fruit amaranth & AMADE \\
\hline & \multirow[t]{3}{*}{ Asteraceae } & Acanthospermum hispidum DC. & Hispid starbur & $\mathrm{ACNHI}$ \\
\hline & & Conyza bonariensis (L.) Cronquist & Asthmaweed & ERIBO \\
\hline & & Emilia sonchifolia (L.) DC. ex DC. & Lilac tasselflower & EMISO \\
\hline & Convolvulaceae & Ipomoea triloba $\mathrm{L}$. & Littlebell & IPOTR \\
\hline & \multirow[t]{2}{*}{ Euphorbiaceae } & Euphorbia heterophylla L. & Fireplant & EPHHL \\
\hline & & Ricinus communis $\mathrm{L}$. & Castor bean & RIICO \\
\hline & \multirow[t]{2}{*}{ Lamiaceae } & $\begin{array}{l}\text { Cantinoa americana (Aubl.) Harley \& } \\
\text { J.F.B. Pastore }\end{array}$ & Catirina & HPYLO \\
\hline & & Leucas martinicensis (Jacq.) R.Br. & Whitewort & LEVMA \\
\hline & Malvaceae & Sida rhombifolia $\mathrm{L}$. & $\begin{array}{l}\text { Arrowleaf sida/Paddy's } \\
\text { Lucerne }\end{array}$ & SIDRH \\
\hline & \multirow[t]{2}{*}{ Rubiaceae } & Richardia brasiliensis Gomes & Tropical Mexican clover & RCHBR \\
\hline & & Spermacoce verticillata $\mathrm{L}$. & Shrubby false buttonweed & BOIVE \\
\hline & \multirow[t]{3}{*}{ Solanaceae } & Physalis angulata $\mathrm{L}$. & Cutleaf groundcherry & PHYAN \\
\hline & & Solanum asperolanatum Ruiz \& Pav. & Jurubeba grande & SOLAX \\
\hline & & Solanum palinacanthum Dunal & Jurubeba & SOLPL \\
\hline
\end{tabular}

brizantha (A.Rich) R.D.Webster, Ipomoea triloba L., Acanthospermum hispidum DC. and Solanum asperolanatum Ruiz \& Pav., which were found 10 months after planting. These species probably have some degree of dormancy, which allows that weed seeds remain viable for long periods and is related with the species rusticity and cycle duration (Mcivor \& Howden, 2000; Vivian et al., 2008).
Only Amaranthus deflexus L., Emilia sonchifolia (L.) DC. Ex DC., Richardia brasiliensis Gomes, Euphorbiaheterophylla L., Eleusine indica (L.) Gaertn., Cyperus rotundus L. and Digitaria insularis (L.) Mez ex Ekman were not found in the sample collected at the end of the growing cycle, probably because of their smaller size and closure of the biological cycle. With the development of weeds and high density in the crop, 
Table 4. Determined parameters of Boltzmann' sigmoidal equation and linear equation fit in the pineapple crop productivity data as a function of the control periods and coexistence with weeds - Détermination des paramètres de l'équation sigmoïde de Boltzmann et de l'ajustement de l'équation linéaire dans les données de productivité de la culture de l'ananas en fonction des périodes de contrôle et de la coexistence avec les mauvaises herbes (Itacoatiara, AM, 2016-2018).

\begin{tabular}{llllll}
\hline \multirow{2}{*}{ Treatment } & \multicolumn{2}{l}{ Boltzmann's } & \multicolumn{2}{l}{$\mathbf{R}^{\mathbf{2}}$} \\
\cline { 2 - 5 } & $\mathbf{A}_{\mathbf{1}}$ & $\mathbf{A}_{\mathbf{2}}$ & $\mathbf{X}_{\mathbf{0}}$ & $\mathbf{D x}$ & \\
\hline Control & 3,047 & 12,866 & 214.72 & 21 & 0.76 \\
\hline & \multicolumn{2}{l}{ Linear } & & & \\
\cline { 2 - 4 } & $\mathbf{A}$ & $\mathbf{B}$ & & 0.98 \\
\hline Coexistence & 13021 & -22.52 & & \\
\hline
\end{tabular}

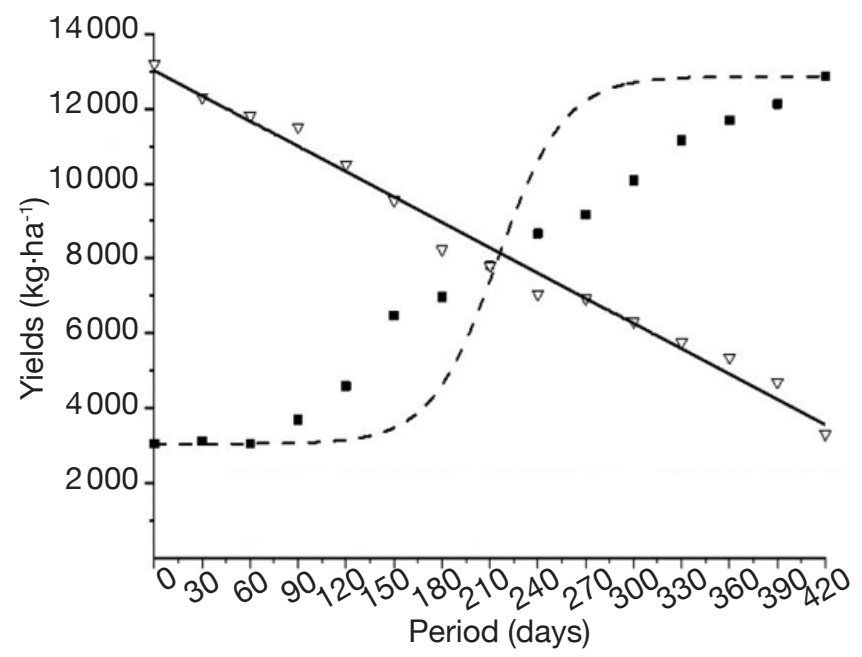

-... Control $y=12866+(3047-12866) /(1+e((x-214.72) / 21)$ $R^{2}=0,76$

$\nabla-$ Coexistence $y=13021-22.52 x R^{2}=0,98$

Figure 3. Observed (symbols) and estimated (lines) pineapple yields according to Boltzmann and Linear equations, as a function of the periods of control or weedcrop coexistence - Rendements observés (symboles) et estimés (lignes) de l'ananas selon les équations de Boltzmann et linéaires, en fonction des périodes de contrôle ou de coexistence adventices-culture (Itacoatiara, AM, 2016-2018).

intra and interspecific competition is intensified, so that the weeds that emerge later and are larger in size cause shading and become dominant, while small-sized weeds are suppressed or die (Silva et al., 2021).

The weeds species that were more representative in the collected samples were $C$. rotundus (although it did not occur in the last harvest), Cyperus esculentus L.
Table 5. Periods prior to interference - Périodes précédant l'interférence (Itacoatiara, AM, 2016-2018).

\begin{tabular}{llll}
\hline $\begin{array}{l}\text { Yield loss } \\
(\%)\end{array}$ & \multicolumn{3}{l}{$\begin{array}{l}\text { Critical periods of weeds control and crop- } \\
\text { weed coexistence }\end{array}$} \\
\cline { 2 - 4 } & PPI & CPIP & TPIP \\
\hline 5 & 14 & 259 & 273 \\
10 & 51 & 204 & 255 \\
\hline
\end{tabular}

PPI: critical period for interference prevention - période critique pour la prévention de l'interférence; CPIP: total period for interference prevention - période totale pour la prévention de l'interférence; TPIP: for two levels of pineapple yield losses - pour deux niveaux de pertes de rendement de l'ananas.

and Digitaria horizontalis Willd. Cyperus rotundus and Cyperus esculentus L. are perennial grasses, a characteristic that enables them to coexist with pineapple plants from planting to harvesting, causing intense interference. According to Quayyum et al. (2000), C. rotundus has a high capacity of infestation and release of allelochemicals in the soil, thus having great importance also for being a species that is difficult to control chemically and/or mechanically (Catunda et al., 2006).

In a study conducted by Catunda et al. (2006) about the interference of weeds in nutrients accumulation and pineapple plants growth, C.rotundus was the species that was more competitive with pineapple for nitrogen and, along with $D$. horizontalis, the species that extracted more phosphorus and potassium from the soil, in response to high density, and interfered adversely with D leaf growth.

The seed-propagating dicotyledonous weed plants most found in the samples collected were Spermacoce verticillata L., Euphorbia heterophylla L. and Leucas martinicensis (Jacq.) R.Br.

\subsection{Productivity and periods of interference of weed plants}

The high rate $(69.5 \%)$ of pineapple yield losses when this crop coexisted with weeds throughout the growing cycle indicates sensitivity of this plant to weeds. Weeds competition with pineapple was favored by the pineapple's slow growing rate, small size and long cycle, where usually emerge climbing weed species and/or of great size, enlarging the shaded area in the crop.

In recent surveys on critical period of weed interference in orange tree and guarana crops conducted in Amazonas State, there was a loss of productivity compared to control of $34 \%$ for orange (Gonçalves et al., 2018) and 65\% for guarana (Soares et al., 2019). 
Considering a maximum acceptable rate of 5\% of losses, pineapple production was affected by the presence of weeds after $14 \mathrm{DAP}(\mathrm{PPI})$ requiring control until 273 DAP (TPIP). The 259 days comprising the interval between 14 and 273 DAP correspond to the critical period for interference prevention (CPIP), when weeds must be controlled in order to prevent irreparable losses in yield or in the quality of the product harvested. The weeds that emerge before or after the CPIP do not affect crop yields significantly (Pitelli et al., 2013).

In a study conducted with pineapple $c v$. Perola, Reinhardt \& Cunha (1984) concluded that the coexistence with weeds affected negatively the crop productivity when it coincided with the first 150 DAP and the time interval between planting and floral differentiation. This finding differs from the ones found in this study, wherein the period of coexistence that affected productivity more adversely was until 259 DAP.

By analyzing the results, it could be seen that in the period from floral induction (300 DAP) and the subsequent fruiting period, the coexistence with weeds caused less damage to the crop yields. Similar behavior was observed by Reinhardt \& Cunha (1984), who found that there was no significant harvest loss when the competition with weeds occurred after the pineapple floral differentiation.

Model et al. (2010) evaluated the effect of weed control on yield, health and quality of pineapple $c v$. Perola in the state of Rio Grande do Sul and found that in the period of 296 days (TPIP), weeding was necessary six times every 49 days on average to ensure better crop yields. These results are different from the ones found in the present study due to different cropping conditions, the variety produced, planting date, soil and weather conditions, as well as the fact that in the referred state the pineapple production cycle is longer.

Although the weeds that emerged 273 DAP, that is, after TPIP, did not affect adversely the pineapple yields, it was observed that the weeds made harvesting more difficult for the treatments with higher crop-weed coexistence, a problem that likely can be solved with mechanical or chemical weeding thirty days prior to harvest.

\section{CONCLUSIONS}

The critical period for weed interference prevention CPIP - lasted from 14 to 259 and 51 until 204 days after planting the pineapple offsets, for 5 and $10 \%$ of yield loss levels, respectively.

The weed interference throughout the production cycle reduced the pineapple yield by $69.50 \%$, compared to the weed control in the same period.

\section{Acknowledgements}

The authors would like to thank the Improvement of Higher Education Personnel (CAPES) and the Amazonas State Research Support Foundation (FAPEAM). We also thank Mr. Maurício de Freitas for giving us the land and many moments with his work.

\section{Bibliography}

Anwar M.P. et al., 2012. Critical period of weed control in aerobic rice. Sci. World J., 2012, 1-10, doi. org/10.1100/2012/603043

Catunda M.G. et al., 2006. Weed interference in nutrient accumulation and pineapple crop growth. Planta Daninha, 24(1), 199-204, doi.org/10.1590/S010083582006000100025

FAOSTAT, 2018. Database Gateway-FAO, www.fao.org/ faostat/fr/\#data/QC/visualize, (06/01/2019).

Ghanizadeh H., Lorzade S. \& Ariannia N., 2010. Critical period for weed control in corn in the South-West of Iran. Asian J. Agric. Res., 4(2), 80-86, doi.org/10.3923/ ajar.2010.80.86

Gonçalves G.S. et al., 2018. Periods of weed interference on orange tree crops. Planta Daninha, 36, doi.org/10.1590/ s0100-83582018360100080

Knezevic S.Z. \& Datta A., 2015. The critical period for weed control: revisiting data analysis. Weed Sci., 63(SP1), 188-202, doi.org/10.1614/ws-d-14-00035.1

Knezevic S.Z. et al., 2002. Critical period for weed control: the concept and data analysis. Weed Sci., 50(6), 773-786, doi.org/10.1614/0043-1745(2002)050[0773:cpfwct] 2.0 .co;2

Marques L.J.P. et al., 2017. Weed interference in eggplant crops. Rev. Caatinga, 30(4), 866-875, doi. org/10.1590/1983-21252017v30n406rc

McIvor J.G. \& Howden S.M., 2000. Dormancy and germination characteristics of herbaceous species in the seasonally dry tropics of northern Australia. Austral Ecol., 25(3), 213-222, doi.org/10.1046/j.14429993.2000.01026.x

Melo M.S., 2013. Indução floral do abacaxizeiro cv. Turiaçu [Ananas comosus (L.) Merril var. Comosus Coppens \& Leal], no estado do amazonas. In: Simpósio brasileiro da cultura do abacaxi, Produção e qualidade com tecnologia e sustentabilidade: anais, 2013, Palmas. Palmas, Brazil: Secretaria da Agricultura e Pecuária do Estado do Tocantins.

Model N.S., Favreto R., Edison A. \& Rodrigues C., 2010. Efeito de tratamentos de controle de plantas daninhas sobre produtividade, sanidade e qualidade de abacaxi/ Effect of weed control treatments on yeld, size, sanity and quality os pineapple. Pesqui. Agropecu. Gaúcha, 16(1-2), 51-58.

Pitelli R.A., Durigan J.C. \& Pitelli R.L.C.M., 2013. Determinação dos períodos criticos na relação de 
interfêrencia entre plantas daninhas e culturas anuais. In: da Silva J.F. \& Martins D., eds. Manual de aulas práticas de plantas daninhas. Jaboticabal, SP, Brazil: Funep, 105-113.

Quayyum H.A., Mallik A.U., Leach D.M. \& Gottardo C., 2000. Growth inhibitory effects of nutgrass (Cyperus rotundus) on rice (Oryza sativa) seedlings.J.Chem.Ecol., 26(9), 2221-2231, doi.org/10.1023/A:1005532802836

Ramos L.R.M. \& Pitelli R.A., 1994. Efeitos de diferentes períodos de controle da comunidade infestante sobre a produtividade da cultura do milho. Pesqui. Agropecu. Bras., 29(10), 1523-1531.

Reinhardt D.H.R.C.\& da Cunha G.A.P., 1984. Determinaçáo do periodo critico de competiçáo de ervas daninhas em cultura de abacaxi perolä. Pesqui. Agropecu. Bras., 19(4), 461-467.

Silva A.F.M. et al., 2021. Matologia: estudos sobre plantas daninhas. In: Arrobas A., Barroso M. \& Takao A., eds.
Matologia: estudos sobre plantas daninhas. Jaboticabal, SP, Brazil: Brazilian Weed Science Society, 7-37.

Silva S.E.L. da, Souza A. das G.C. de, Berni R.F. \& Souza M.G., 2004. A cultura do abacaxizeiro no Amazonas. Circular técnica No. 21. Manaus, AM, Brazil: Embrapa, 6.

Soares D.O.P. et al., 2019. Period of weed interference in guarana crop. Planta Daninha, 37(3), doi.org/10.1590/ s0100-83582019370100070

Vivian R. et al., 2008. Dormência em sementes de plantas daninhas como mecanismo de sobrevivência: breve revisão. Planta Daninha, 26(3), 695-706, doi. org/10.1590/s0100-83582008000300026

(19 ref.) 